\title{
EXPERIENCE OF FOREIGN COUNTRIES OF DEVELOPMENT OF PERSONNEL POTENTIAL OF PUBLIC ADMINISTRATION IN THE SYSTEM OF STATE-MANAGEMENT ACTIVITIES
}

\author{
Oleksandr Akimov ${ }^{1}$ \\ ${ }^{1}$ Doctor of Science (Public Administration), Assistant Professor, Interregional Academy of Personnel \\ Management, Kiev, Ukraine, e-mail: 1970aaa@ukr.net; ORCID: https://orcid.org/0000-0002-9557-2276
}

Ukraine's independence, radical change of priorities in relations between a person and the state, when a person, his life and health, honor and dignity, immunity and security are recognized in Ukraine as the highest social value (Article 3 of the Constitution of Ukraine) [1], have led to the need to systematize all spheres of public administration on the basis of democratic principles of functioning of the state and law. Such a significant change in values in society could not but reflect on the need to develop means of satisfaction and ensuring the needs and interests of society, the state and the person. And, above all, it influenced the need to form and develop public administration in a new way, as a complex systemic formation, which, at this time, acts as the most widespread and effective means of implementing legal norms to meet and meet the needs and interests of society [2].

Today marks the relevance of determining the personnel influence in ensuring public administration in Ukraine and foreign countries on systemogenesis, in general, public administration and, in particular, public management activities. The analysis of the international experience of personnel support of public administration will allow to determine the directions of systemogenesis in the process of development of national public administration, will have a positive impact on the formation of an effective system of personnel support, will help to overcome the existing negative trends in our country, taking into account the mental characteristics of domestic society. The study of the problems of personnel support of public administration bodies in Ukraine, today, is the subject of interest and research requests of both managers and scientists.

After all, the expediency of building a proper systematic personnel policy, a significant change in the better direction and placement of personnel is analyzed in the works of leading Ukrainian scientists: V. Averyanov, S. Dubenko, V. Knyazeva, T. Kaganovska, V. Lugovoi, N. Nyzhnyk, V. Oluyka, N. Protasova, L. Prokopenko, S. Seryogin, etc.

Personnel support of public administration is a key factor in the systematic approach in public management activities. The presence of direct dependence of the results and productivity of state-management activities from its personnel and personnel potential [3], which, in turn, has an impact on the life of the state and the welfare of all its citizens, the international authority of the country. Conducting 
research on the issue of personnel support of public administration, it should be noted that regardless of the different approaches in determining the issues of personnel support of public administration, stability and efficiency of the state apparatus is achieved only through the preservation and improvement of professional personnel who have extensive experience in public administration [4].

For a long period in our country was undervalued, and sometimes just negative attitude to the practices of developed countries in the field of public system and public administration. Such experience was not taken into account from ideological beliefs, at best, it was settled only as cognitive information. The problem of adaptation of the staffing of public administration to the conditions of today is a cornerstone in modern conditions. It is necessary to bring the system of personnel management in good condition and in accordance with the realities of today and, on the example of international standards, which causes the need for political figures to form and approve the program of reforming the civil service, in order to radically modernize it [2].

The basis of the systemogenesis of public-management activities in most countries are the following principles: democratization of public administration and public service; orientation to the average citizen who, being a client of public services, acts as a consumer of public services; orientation to the final result; profitability of management; ease of management. Governments of different countries introduce new ideas of public management, which provide for widespread use in public management activities of methods of work used in the private sector. Among such methods are the following: methods of strategic planning, collective nature of work in the decision-making process, assessment of the quality of performance of official duties, reducing the number of levels of management, establishing the conformity of employees' earnings from the number, quality, complexity of work.

It is advisable to note that regardless of the difference in approaches to personnel support of the civil service, resilience, stability and efficiency of the state apparatus can be achieved by preserving and improving professional staff who have significant experience in government and management, their composition is largely unchanged during the parliamentary elections and other changes in political situations. This order is possible to provide a high level of professionalism of the civil service [5].

It is also advisable to point out that government departments in the course of their powers are attracted by the support of local institutions of each state in particular, and unitary policy of the government prevails in departments of all levels. They create separate personnel units that conduct the selection, evaluation and admission of civil servants to positions. 
By comparison, in the UK civil servants in government make up approximately $6 \%$ of the total employed population, and in France - 15\% [6]. At the same time, in the U.S., in addition to employees in state power and management, public service employees are enrolled in the sphere of communal services and postal services. In France, civil servants are also persons employed at work on a permanent basis by the state, local authorities, as well as a number of government agencies. The category of civil servants includes those persons who have employed on a contractual basis in public institutions that embody the functions of civil servants, however, their labor functions are regulated by the norms of private law (social security bodies can serve as an example).

Also, this category includes employees who are on contract support in joint stock companies belonging to the public sector of management. Such delimitations are explained by a different interpretation of the concept of "civil service", which is formed in accordance with the concept of civil service, which is formed specifically in each country.

The concept of "civil service", which are used in a number of countries, can be called the concept of "public service", "civil service". However, in the US, the term "civil service" is endowed with a much smaller range of functional duties, but rather than the concept of "public service." It covers only employees of public institutions. This category does not include positions on an elected basis, which are involved in the field of jurisprudential. Also, officials of police agencies do not belong to this concept of positions stipulated by the Army and Navy staff. The world is rapidly gaining momentum towards reducing the composition of managers and reform by attributing many positions of public servants to the private sector.

At the same time, a significant decrease in the number of personnel is carried out, which creates a reduction in the system of management structure, improvement of the procedure for development and adoption of management decisions. Such vectors are aimed at a much more rational use of taxpayers' funds. This money should be used for the necessary programs for citizens in order to achieve the goals and fulfill the goal. The quality of state management activities under these conditions is assessed according to the final result, which will lead to improvement of the level of organization.

Most clearly, the principles of rational organization of personnel support of public administration are enshrined in U.S. law. Among such principles are the following: selection and promotion of personnel should be carried out from all walks of life, exclusively on the basis of the abilities, knowledge and skills of candidates, as a result of fair and open competition, which gives all equal opportunities; equal treatment of all applicants and fair treatment in the process of personnel management, 
regardless of political views, race, color, religion, national origin, sex, marital status, age or disability, with respect for privacy of personal life and constitutional rights;

equal pay for work combined with encouraging and recognizing excellent performance of work, as well as, taking into account the national and local level of remuneration of private sector workers, to provide incentives for good work in the civil service; preservation of successful employees, correction of substandard work, dismissal of those who cannot or do not want to improve their work;

officials should be protected from prosecution for lawful disclosure of information about violations of laws, rules and instructions, as well as substandard management, significant waste of public funds, abuse of power or threats to public good and security [7], [5].

As for the U.S. Civil Service, it consists of a competitive and exceptional one. According to the name "competitive" - this means that the persons who are appointed to such service must pass proper competitive selection, which takes place on the basis of exams. In the total population, more than $90 \%$ of civil servants must make a competitive selection. After all, in the U.S., exams are considered the only democratic way that can ensure compliance with the principle of equality of access to employment in public service, as well as, is the most effective method of personnel recruitment, because they allow to single out the more suitable and most complex public servants.

Although, this system contains a number of positive elements, however, critical points regarding the competition procedures themselves are also followed, because a significant amount of financial resources are lost during its implementation, and significant advantages of those persons who were able to get a better level of knowledge and more prepared ones are also significantly followed. Therefore, we consider it appropriate that for our society it will be significantly costly to unprofessionalism of civil servants, therefore, it is worth improving the procedures on a competitive basis of selection for all, without exception, civil service positions in Ukraine with proper improvement and adaptation to the conditions of today.

Researcher T. Tarasova rightly indicates in his scientific work about the exclusive civil service in the U.S., which is regulated by special regulations and is not subject to the general law on civil service. Such "exceptional" officials are considered persons from the personnel of the National Security Agencies, the CIA, the FBI, the State Departments and the U.S. representation in international organizations. Due to their specifics and peculiarities of work and in order to create the safety of state interests, in these structures personnel recruitment is carried out on other grounds, respectively, such employees are guaranteed a higher salary [8].

Such candidacies, which have characteristics in accordance with the requirements established by law, have the right to qualify for the relevant position 
within the American public services. As practice shows, during such selection up to five persons with the highest qualification qualities are selected, whose candidacy is then submitted for consideration by a special official who makes decisions impartially and does not assume favoritism and discrimination [9].

For a significant number of U.S. officials, the promotion of official stages is carried out in accordance with the principle of merit systems, that is, the selection of the most competitive candidates for official promotion in office is carried out on a competitive basis during exams, as well as, on the basis of an annual evaluation of their official achievements. Today, each agency has a separate gradation of such official successes and special evaluation criteria.

Employees themselves are also able to be involved in the development of evaluation criteria. The study of working achievements serves as the basis for deciding to raise, downgrade, send for training in order to improve qualifications, reward, leave in office or replace a civil servant with another person, that is, dismissal.

Heads of institutions should inform employees about the presence of critical comments on their activities and the annual assessment of their work. Before starting any activity related to demotion on the basis of poor characteristics of labor of civil servants, they should be warned in advance in writing. In case of receiving a proposal relating to downgrade to official positions, employees during the annual period of time have the opportunity to demonstrate positive work, it will serve as a basis for withdrawing such a proposal. A forward-looking plan for promotion is being developed across all U.S. public services agencies. If there is insufficient number of candidates from the unit for a certain position, an open competitive selection will be announced and held.

Qualification standards for personnel promotion are developed independently by each agency. Such standards define a minimum level of requirements for successful performance of relevant official functions. We agree that such experience of decentralized definition of standard requirements in each individual agency is extremely positive, so we consider it appropriate to implement it into the domestic state apparatus, given its significant branching and extremely large number of functional duties performed by officials.

At the same time, U.S. regulations prescribe a requirement to apply disciplinary measures to such managers who: discriminate against any of the candidates for the position; require such applicants unforeseen by law materials that are not related to the evaluation of the work he has done or their abilities, inclinations, general qualifications; apply the official powers granted to them in order to force them to commit political actions; deliberately deceive the person and make obstacles to exercise the right to take part in competitive exams for public service; 
to influence the civil servant in order to obtain his refusal to participate in the contest, or to deteriorate or improve the chances of any of the candidates; give such an advantage to candidacies that are not provided for by the current legislation; appoint, promote the service of persons with a family affinity; commit or attempt to commit personnel actions in the form of punishments for such officials who have exercised their legal rights to file appeal proceedings, refused to carry out certain political activities or legally exposed violations of the laws, rules and instructions, impracting financial expenses of funds, abuse of powers or significant threat to the health of persons or public danger;

carry out or attempt to take actions against personnel who are not prescribed in the legislation or are found to be misconduct by law, violation of the rules and instructions that regulate the principles of the systems of encouragement [10]. Promotion on official ranks takes place in different ways and depends on the ranks of the position held or the position being replaced. As for administrative and political leaders, they are appointed by the relevant ministries for civil service.

In such ministries, special selection committees have been created to decide on the appointment of civil service management staff. The Committee has a special confidential computerized list of all states of higher administrative bodies and contains data on education, work experience, professional skills and competence of such employees.

For another category of officials, annual reporting is practiced, which is conducted at the levels of a separate ministry. All reports are submitted to those officials who are one or two steps above those employees for whom reports are generated. Reporting is conducted to the Council on the promotion of employees in accordance with ministries. Members who are part of such a Council are appointed by ministers who are already the last links in deciding on the appointment of officials whose candidacy was nominated [11].

In the U.S., there is largely an encouragement to the mobility of staff of government officials. Thus, they have the opportunity to acquire new knowledge and develop a number of skills, establish new acquaintances with employees of other structural units, expand their outlook and get to open other prospects for their career growth and personal development. U.S. agencies own a system of regular labor evaluation. At the same time, the purpose and indicators according to which such assessment is carried out are determined, together with self-assessment, the conclusions of the manager. In order to grow career, all officials are obliged to systematically attest.

In 1979, the Service of Senior Executives was founded in the United States, which aimed at providing a talent pool for both career and politically appointed persons, increasing the business qualities of administrative staff, reducing problems 
admisting in relations among career officials and those who were politically appointed, also performed a number of coordinating tasks in the field of human resources management.

Special qualification requirements were established for admission to the Service of Senior Executives. The announcement of vacant positions was kept open for 14 days. In the case when the person first claimed this position, his qualification and managerial skills were evaluated by a specially created commission consisting of three members of this service, who had to be representatives of different agencies.

In addition to competitive tests, there are also alternative ways of appointing to positions in the Senior Executive Service, namely, when a person participated in the training programs developed in the Human Resources Service. However, not everyone can get training, because the selection of participants is also carried out on the basis of the competition. For newly appointed members of the Senior Executive Service, a probationary period of one year is set [12].

In order to obtain a staff officer much more flexible functional duties, in addition to permanent appointment, it is assumed that there is a possibility of temporary and emergency appointment. Appointments for a temporary period take place only lasting up to three years and, if the agency has an urgent need for prompt adoption of an employee for the purpose of performing special projects or specific important functional duties, and the usual procedure is not possible to carry out due to its longevity. Emergency appointment is carried out lasting no more than 18 months and in case of urgent need.

In the U.S., to date, there are fourteen government departments, where the civil service attracts more than $85-90 \%$ of the total number of all employees of the federal public service [13]. For local departments, the general structure is normatively prescribed, however, their structure can vary significantly by quantitative composition and have a completely different range of functional powers. All departments are headed by the secretary appointed by the president subject to prior approval by the Senate. Deputy secretaries and their assistants, respectively, are politically appointed. With this sign of the U.S. civil service, it can be distinguished from the British one, in the latter, officials holding the position of the relevant position of deputy secretary, working as employees on a permanent basis.

Prior to the department's order, the departments include bureaus, zovich, and professional officials, not individuals, who are assigned to the church. Up to the butt, Statistical bureau prats are a warehouse for the department of the well-made kervnik of the great burden of discretionary possession, wanting, colo yo foot-and-water ovs'ekz'yak in the rule of law that's legality on the housing of the adaign.

It's just like that, so the departments in the course of the Viconan of their own will be filled with the pertrim-chy-set staff of the zokrem, that unytarnary polishor 
the order of the lord's at the households of the sachit of the ants of the ants. They have a place to do their cadres, yak, and the people of the country.

As for the interpretation of the concept of "civil service" in France, it is advisable to consider in a broad sense "the performance of professional duties by agents in the service of the state, the territorial team, the public institution and in general in any administration". In a narrow sense, the concept of "functionary" unites categories of such employees as military, judges and applies only to those who are employed in permanent service in public administration and are part of its formed staff. Accordingly, temporary employees do not belong to the category of "functionalists" [7].

The French state service is so well over the special characteristics, yak vioremlu itself managed the knowledge in the service of the police body in the galuz of the power service. Tse's pre-volyauvati will be active in the new professional assets in the ranks of the community. For the adoration of the tsei, the meth is to be made a measure of the power-up, the full-back organ, up to the butt, such organs can be called general's joy, Teritorizalna radiate, Parity of administrative command, i'm borrowing to the uzgogen people of the law-making acts in the spheres of powermanagement service, that for the farewell of the "insurance service" in the power services, negotiated alternatives to the led-off design service. On the first of the Usa, the pre-qualms of the conceptual p.d.- at the special services of the power aparat, The Franzya is afraid to over-pass the end-of-ends of the non-regular first-time service preparations to the Viconann of them ad-tracative those technical districts.

The power of the service of The French is key to the official's personnel in the respect of the high-ranking culture, appendages of the Vicinouvati of the real-world that competently virtual food. In France's powerful services, I'm going to have to do this: the function of the service, I confess to planting the non-construction-free one, and I'm going to put on a lot of work. I don't want to admit to my position on the contractual basis. The middle of them is a medium, seasonal robes, servicemen on the minds of the mid-time " pay prats" and etc. [14].

Attracts our attention from a scientific point of view the peculiarity of the procedure for holding competitions for the replacement of vacant positions of civil servants. It establishes ways of distributing public positions, which are extremely limited on the basis of competitive examinations. This procedure allows experts who are part of an independent collegiate body (jury) to classify the contestants appropriately in accordance with their merits for further submission to the position [15].

In France, three types of contests are practiced:

1) "external", appointed only to candidates who enter public service for the first time; 
2) "internal" - for employees who have the appropriate work experience for the purpose of personnel promotion;

3) "open" - can pass all those who have certain standards of requirements prescribed in the legislation.

The competition is announced by the resolution of the relevant minister or other person authorized to conduct such actions. This resolution specifies the type of competitive selection. On this basis, the competition committee is selected from among the most competent professionals who have an impartial attitude to the contestants, are completely independent from the views and visions of the administration. Usually, the competitive selection consists in submitting a written report and passing an oral exam. Throughout the time all the time allotted to perform written competitive tasks, the principle of anonymity must be strictly observed. The written exam usually takes place in extremely different forms: the contestant needs to edit the text task, prepare and write a defined dossier. During the oral examination, the general culture of candidates, possession of their special knowledge, as well as conducting a check on the subject of logical statement of their opinion are evaluated. Sometimes candidates can also perform test tasks [16].

According to the results of the examinations, the jury compiles a list of those candidates who are fit and rank them depending on the scores received. The jury is empowered and right not to approve any of the candidates or submit them less than the number of vacancies, as well as to form additional reserve lists of them. However, this powers of the jury are not completed. Their positive recommendations provide not only an opportunity, but also give rights to obtain relevant positions. The same appointment is made by the authorities or the person who announced this competition. The organizers of such competitions should also take into account what the jury recommended them: compliance with the submitted list and establishing in accordance with it the ranking of candidates, however, it is allowed and completely refuse to be appointed to the vacant position. The Administrative Court is endowed with controlling functions regarding the legality of the competition and the implementation on their basis of appointments.

Any participant of the competition has the right to appeal the result of competitions or file a lawsuit, in case of disagreement with the appointment, according to its results. In case of filing an unsubstantiated complaint, the results of the contests will be canceled and it will be re-conducted.

Competitive selection is only one way to select and promote personnel stages of officials. Other procedures are also legally admitted - for example, fitness lists, professional exams or, in some cases, arbitrary choice of candidacies are made. According to belonging to the general status, the process of personnel promotion of officials in France is to increase in office or rank. Promotion on staff steps takes place 
together with the increase in wages directly to the work experience of the official and the assessments he received on the exam. Promotion in offices is carried out in two ways. The first of them is the entry of the official into the annual lists of applicants for the increase, which is formed on the basis of the received decision of the administrative parity commission and the results of the annual evaluation, taking into account the work experience for the service of years. The second - at the training of professional selection, which is carried out by passing a special professional exam.

Consequently, we consider the statement of I. Vasilenko to be substantiated that one of the key elements of the career of civil servants in France is determined by "guarantees of slow, however, correct advances in service years or by senior ranks of stay in a public institution. Such principles are almost entirely excluded in the U.S., where there is no automatic advancement in official steps" [7]. In our opinion, this serves as a key aspect of the superiority of American human resources systems. The French civil service system is by its very nature determined mainly by career peculiarities. In it, an employee who is appointed to the position of a civil servant is forced to spend his entire professional life in only one organization, which is determined by a specific hierarchy. The organization is provided with a well-known automatism for the promotion of official ranks.

It is advisable to understand that, in the presence of such a system, there is a provision of social stability of civil servants, as well as contributes to their interest in staying in public service, however, this leads to no incentives to show initiative and creativity in approaches to work. The French system of training, retraining and advanced training consists of a number of elements. Universities, law and political institutions provide training and professional training for future positions in public service. Students receive fundamental theoretical knowledge and practical skills of readiness, which will be able to be used while working in senior positions in the system of public administration, having previously passed a number of stages of professional growth and development.

As for the training and retraining of personnel, it is carried out in specialized institutes: the National School, departmental administrative institutions. It is also advisable to note that the training and advanced training of civil servants is focused on the requests of the relevant authorities and agencies. The educational process without interruption from production is a traditional type of training, during which there is an exchange of practical experience, familiarization with advanced techniques, improved cognitive level and acquired appropriate skills directly in the process of performing official duties. Training by internship is carried out during practice in a particular position on the basis of a special educational program and under the close supervision of highly competent specialists. 
This form of education aims to prepare the intern for the professional performance of his future job functions. It should be noted that internships can periodically take place for experienced civil servants before taking a new position. Training of personnel can also take place in the form of educational creative leave, which is paid by the administration and which is provided at the request of the employee of the state apparatus for a period not exceeding a total of three years for the entire period of his/her stay in the service. Academic leave is used in order to obtain new management skills and skills of working with personnel, more fundamental knowledge in the field of theory of management, political science, economics, legal norms, the latest management technologies and other disciplines. The practical orientation of this kind of training serves as a great advantage of it.

Compared to the higherly considered advanced training systems, in England the promotion system is characterized by significant strict rules at all its levels. Accordingly, the chances of advancing on career levels or the possibility of transition from one ministry to another are extremely limited. Of great importance, traditionally, is given to senior officials in ministerial hierarchies. The system of selection, training and promotion of service ranks in the UK is organized in such a form, which contributes to the formation of types of professional managers, widely profiled administrators. Political leaders in ministries especially appreciate this kind of highly professional leaders, or "generalists", in accordance with the terminology, which can turn the opinions of experts into concrete and meaningful proposals and practical projects that will be understandable and accessible to other civil servants and society in general.

The advantages of attracting generalists in the public sector of management is that it greatly simplifies the solution of the problems of general coordination, through their neutrality and experienced work, they are able to assist in finding a balance to reach consensus in meeting various management requests.

In the work of the famous English political scientist D. Stül, attention is paid in detail to the field of generalist activity, which aims to summarize the experience of the entire apparatus of the state mechanism, only if the expert functions in the relevant fields of their activities are terminated [17]. However, recently, the UK has seen a tendency to increase the number of supporters of strengthening the role of professionals in public administration, such as the American model.

However, proponents of specialized administrators point to the need for the development of a modern system of public administration, so generalists are not managed to properly cope with the ever-increasing volume of tasks, so a significant amount of time of experts will be spent to formulate and describe the problems that have been created and in order for the interpretation to be simple and accessible formulated. Another argument in the need for professional staff is the presence of too 
much emphasis on improving the management system itself in general, which causes significant damage to specific areas and profile tasks. This leads to a decrease in the effectiveness of the entire system of public administration.

In the UK, the recruitment for civil service relates to the professional competences of the Civil Service Commissions. To do this, a typical general written exam was introduced, the conduct of which serves as the main condition for entering the civil service. The exam is based on the issues of professional curricula of leading universities - Oxford and Cambridge. Therefore, as practice shows, it comes down to the fact that it is these universities that train and train a large part of candidates for senior management positions.

As for Germany, here the appointment of federal civil servants to the post is held by the Federal President or another authorized institution. The applicant is considered to be appointed to the relevant position immediately after awarding him certificate of appointment. This document contains details about the types of official relations ("lifetime", "for the exam period", "as an honorary servant" , "for the time"), which, accordingly, is an indication of the period for which the appointment is carried out. In case of changes in the essential conditions of official relations or features of work, the definition of a new status of the employee is made, and, when the relevant position is granted, its name is indicated. In the case when such a certificate will not be established by the legislation of the requisites and does not comply with all forms, the appointment of the officer will be considered invalid.

Probation during the civil service in Germany can not exceed a five-year term. Appointment to public service takes place only in case of successful passing of probation and achievement by a person of 27 years of age. In the case when a person claims to be the head, he/she must guarantee his/her willingness to defend the constitutional order, proclaim an oath of compliance with the Basic Law and all applicable regulations of the Federal Republic and faithfully perform his duties. In addition, the future official needs to have the necessary professional training, the specifics and type of which is prescribed in accordance with the busy rank of the service hierarchy.

German law provides for 16 groups of officials: A1-A5 - low officials (auxiliary and technical); A6-A9 - middle offices (government secretaries, ober-secretaries, haupt secretaries); A10-A13 - higher positions of the first degree; A14-A16 - higher offices of the second degree (senior government advisers). To get admission to the service of lower levels (A1-A5) you need to: successfully finish the main comprehensive school or recognized as equivalent level of education, as well as undergo preparatory practice in future specialization. For secondary levels (A6-A9) it is necessary at least the following: to finish a real school, to pass preparatory practice 
for one year, to pass the exam. Significantly higher requirements relate to higher levels of employees (A10-A16).

Only those who successfully graduated from high school, have received special training for three years and passed the corresponding exam are allowed for service at the highest levels of the first degree (A10-A13). Finally, only those who received higher education and passed the first state qualification exam are allowed for service at the highest level of the second degree, have received proper training in the service for two years and successfully passed the second exam [5].

To the categories from which the recruitment of personnel of officials takes place, the historical priority is given to justice, and then - from the category of economists and the field of social sciences. It has already developed traditionally that mastering the profession of a lawyer in Germany is the best opportunity to enter public service. Despite the mass of requests for positions in public service in the state apparatus, all the same, lawyers still hold leading positions at all levels of the system of ministries. This approach is associated with the state realization that officials with legal education will be able to take care of the protection of laws and be their creators.

It is fundamentally advisable to cover the issue concerning the remuneration of civil servants under German law, because it spells out a sufficient amount, which will be possible to ensure the proper level of residence, in order to devote itself to their profession. After all, only such an employee, who is financially secured, will be able to fairly and lawfully perform the duties assigned to it. All issues concerning salary are settled by a single regulatory framework, and these rules of law are valid in the Federation, lands, municipalities, municipal associations, bodies, institutions and funds acting as subjects of public law. Features that are characteristic of individual lands can be taken into account only in cases that are clearly regulated by law [4].

At the legislative level, the issues concerning the handling of personal affairs of civil servants are also settled. The employee is given the right to personally decide who to allow for a review of his personal case. It is necessary to inform the manager in advance about the presence of all complaints against him or negative conclusions about his activities, before entering the information about it in the personal case. Also, all his thoughts and views on such grounds are recorded and made to the personal case.

German civil servants are obliged, due to official necessity, to work overtime. In the case when such overtime exceeds five hours a month, he will be able to get an additional free day from work. Civil servants are not endowed with the right to carry out any business activities personally or through trustees, nor are they entitled to be members of management activities or to participate in the work of supervisory boards 
or in another body endowed with management functions, or to work in a commercial organization of any other legal form.

Civil servants for employment in any other job, except the main one, should obtain a preliminary permit issued by the highest official authority. Such permission is not necessary only in case of establishing guardianship, care for the sick or infirm, fulfillment of duties concerning wills, creative activities, disposing of their own property, as well as activities related to the educational sphere, professional scientific researches in institutions. Civil servants are endowed with the legislative right to leave with the preservation of wages to participate in elections and referendums, as well as to run for a seat in parliament, the fulfillment of honorary duties stipulated by law.

The system of official promotion is regulated in detail by the legislation and is based on two principles: advanced training (which is confirmed either by a special check and an appropriate assessment, or by passing a special exam) and the principle of gradual advancement (alternate passage of steps). Exceptions to the two rules are allowed only if there is a special permit from the Federal Personnel Commission [4].

For each official group, promotion requires proper professional training and successful passing of the exam period. Their increase in service is possible in the case when the official activity will be assessed "very good". When the state, represented by the head, does not comply with its obligations to advance on career stages, the amount of wages or in other cases, the official has the right to claim compensation for damages and payment of losses.

The employee can be transferred to the service within the sphere of official powers of his employer on the basis of a personal application or subject to official necessities. However, the process of transferring to another agency without the consent of the civil servant is allowed only if there are similar conditions of service and equivalent, compared to the previous place of work, salary. Transfer of civil servants to the subordination of other employers is acceptable only with the consent of the employee himself.

The experience of organizing China's civil service deserves attention. In 1993, the PRC adopted the Regulation on Civil Servants, which includes the following chapters: general provisions; rights and obligations; categories of positions; hiring; evaluation of work; compensation; discipline; official promotion and decline in the post; appointment and dismissal; preparation; replacement; mechanisms for preventing shortcomings and conflicts; fee, insurance; resignation and dismissal; retirement; complaints and appeals; personnel management and control [5]. With this in mind, the Chinese human resources service has the principles of openness, equality, competition and selection during the reception of personnel by conducting exams. 
However, it is quite interesting that in China the professionalism of civil servants is always combined with their political preferences and beliefs and belonging to communist ideas. Article 16 of the Regulation prescribes the appropriate procedure for passing into public service: to begin with, a notice is published in the local press about the presence of a vacant position; checking the professional competences of all applicants; then they make an open exam; political, ideological and moral qualities are checked, work fitness is determined; according to the results of examinations and the results of inspections, the lists of persons applying for enrollment to the relevant service departments are being trained. Persons who were first enrolled to work in the state apparatus must pass probation within one year, after which, those persons who were able to comply with all professional requirements, are subject to official appointment to the relevant position.

Civil servants who have been enrolled in the bodies of people's governments of provincial levels and above, it is advisable to have at least two years of working experience in positions of a low level. It is expedient to see the proposal for the implementation of similar restrictions, as well as in Ukraine, in order to clearly understand the life situations and problems of society by senior civil servants.

The most significant duties of Chinese employees include the following: strict adherence to the Basic Law and regulations; performance of official duties in accordance with the current legislation, bylaws and political factors of the state; maintaining close relationships with citizens, the ability to listen to the opinion of the people, to perceive the verification and control of their activities by the public, the persevering service of realization of the interests of the people; ensuring the safety, honor and compliance with the interests of the state; preservation of public and official secrets, justice, honesty and unselfishness, selfless service to the state.

Civil servants in the Republic of China have the full scope of powers they need to implement their official functions. There may be no shift from positions, downgrades, resignations or use of administrative penalties due to the lack of proper grounds for this, which are legally prescribed, and, in the case of improper compliance with the established procedures. Chinese civil servants receive proper wages, have the opportunity to use the full amount of insurance provision and all existing insurance payments. Legislatively, civil servants are endowed with the right to freely discuss and evaluate the activities of administrative bodies and their leaders, freedom of expression of critical comments and the possibility of making their own proposals in order to improve it.

The concept of rotation of civil servants in China is a significant theoristpractical interest, because it covers the procedures and ways of transfers to other positions, internal movements of employees in a public institution, the specifics of appointments and replacement of positions, as well as the issue of business trips for 
the purpose of hardening. Century. 56 The Regulation prescribes that it is advisable for state administrative bodies of all levels to own a certain amount of vacant seats for the acceptance of transferred, transferred or undergoing the procedure of appointment to replace the position.

If the concepts of "transfer to other positions" and "movement by position" are also known in domestic jurisprudential, as for other terminology, it is absent in the national legislation. The appointment to replace the vacant position in Chinese law is spelled out as a process of systematic substitution of leadership positions and many other positions in various spheres of work and activity.

During the business trip for the purpose of hardening, the procedure of systematic selection of civil servants who occupy the relevant positions is understood in order to move them to the bottom of the institution, enterprise or other organizations. During the European integration processes, interesting experience was accumulated in the field of regulatory and legal settlement and ways of coordinating the activities of public services of countries that entered the CIS, as well as the formation of a supranational body, interactions of employees within pan-European political institutions of different states.

The system of state-management activities in our country is largely aimed at achieving tasks related to modernization of all spheres of public administration in foreign countries, namely: improvement of efficiency of work, rational construction of management structures, simplification of procedures in management, democratization, achievement of high results of activity.

When borrowing elements of foreign institutions in the field of human resources, it is advisable to pay attention to the key provisions. First of all, it is advisable to propose the development and development of appropriate programs for their implementation, taking into account the specifics of domestic governance. Secondly, regulatory, financial and organizational support of the introduced novelties should be implemented. Thirdly, it is advisable to conduct approbation of different models of organization of personnel support in the form of experiments. Thus, it is necessary to develop mechanisms for controlling the progress of implementation and checking its effectiveness.

\section{References:}

1. The Verkhovna Rada of Ukraine (1996), The Law of Ukraine "Constitution of Ukraine". URL : https://zakon.rada.gov.ua/laws/show/254\%D0\%BA/96-\%D0\%B2\%D1\%80\#Text.

2. Akimov, O. O. (2017), "Analysis of professional activity of civil servants of foreign countries: aspects of personnel management", Publichne uriaduvannia, № 1 (6), pp. 16-29.

3. Akimov, O. O. (2016), "Personnel processes in public administration", Teoriia i praktyka derzhavnoi sluzhby [Theory and practice of civil service], materialy naukovo-praktychnoi konferentsii [materials of the scientific-practical conference], DRIDU NADU, Dnipro, Ukraine, 99-101.

4. Akimov, O. O. and Rybak, I. P. (2014), "Public administration staffing: the experience of foreign countries", Stratehiia i taktyka derzhavnoho upravlinnia, № 1, pp. 137-144. 
5. Kahanovska, T. Ye. (2010), Kadrove zabezpechennia derzhavnoho upravlinnia v Ukraini [Public administration staffing in Ukraine], KhNU imeni V.N. Karazina, Kharkiv, Ukraine, 330 p.

6. Hosudarstvennaia sluzhba. Obshchye problemi. Zarubezhnbii opit [Civil service. Common problems. Foreign experience], Moscow, Russia, $144 \mathrm{p}$.

7. Vasylenko, Y. A. (1998), Admynystratyvno-hosudarstvennoe upravlenye v stranakh Zapada: SShA, Velykobrytanyia, Frantsyia, Hermanyia [Administrative and public administration in Western countries: USA, Great Britain, France, Germany], Logos, Moscow, Russia, 200 p.

8. Tarasova, N. Y. (1992), Hosudarstvennble rabotnyky SShA [USA government officials], Moscow, Russia, $240 \mathrm{p}$.

9. Stryzhov, S. (1992), “Advanced training of managerial staff: the experience of the United States", Rossyiskyi ekonomycheskyi zhurnal, № 7, pp. 65-67.

10.Freid, Z. (1998), Vstup do psykhoanalizu [Introduction to psychoanalysis], Osnovy, Kyiv, Ukraine, 709 p.

11.Sylyn, A. (1992), "Personnel services and methods of employee evaluation (foreign experience)", Chelovek y trud, № 2, pp. 46-57.

12.Lobanov, V. V. (1996), "Senior Management Service in the United States”, Hosudarstvo y pravo, № 6, pp. 131-139.

13.GIick, N. (1990), “An Outline of American Government”, USIA, 47 p.

14.Les functions publiques de l’Europe des Douze (1990), Revue francaise d'administration publique, № 55, $507 \mathrm{p}$.

15.Stul DR. Britain (1979), Government and Administration in Western Europe. Oxford, pp. 48-49.

16.Civil Service of Germany (1977), Hosudarstvennaia sluzhba osnovnblkh kapytalystycheskykh stran, pp. 256-265.

17.Giobin, Zhu. (1995), "Reform or reorganization: constructing and implementing the new Chinese civil service”, International Review of Administrative Sciences, vol. 61, № 1, pp. 236-245. 